\title{
THE ITALIAN ARBERESH AND ALBANIAN NATIONAL CASE
}

\author{
Dr. MAJLINDA PEZA(PERRIU) \\ UNIVERSITY: "ALEKSANDËR XHUVANI", ELBASAN , ALBANIA \\ majapeza@yahoo.com \\ MSC. ANDRIOLA KAMBO \\ UNIVERSITY OF TIRANA, ALBANIA \\ andriolakambo@yahoo.com
}

DOI:10.5901/mjss.2014.v5n19p651

\begin{abstract}
This scientific research through the accumulation of facts, historical resources and their interpretation aims to give a full panorama of the whole contribution of the Italian arberesh to the Albanian case at the end of the XIX-th century until the first decade of the XX-th century. Exactly by beginning at the end of the 19th century in the south of Italy it will begin to loom an Albanian literature with an authentic national content. The well known representatives of such a literature would be important figures in the rows of the Arberesh Italian - Albanian community who had achieved to conserve a clear Albanian language and traditions. Also the Italian-Albanian periodic press like "Fiamuri Eve", "The Albanian Nation" that were created during this period would become the forums for the disclosure of their political thoughts and ideas about the fate and the future of the Albanians that lived under the rule of the Otoman Empire at the end of the 19th century. Among the initiators of such a movement at this period would be Jeronin De Rada, Dhimiter Kamarda, Zef Skiroi etc. Their activity would be displayed through their wide multi-aspect creativity which is evidenced in the literature, scientific, cultural, publicist political and patriotic aspect. Of a particular importance would be considered their ideas and projects in the funtion of creating an autonomous Albanian Vilayet. All their activities will serve a single purpose and will developed in order to support the solution of the Albanian nation political case and will find the full support not only of the Italian-Albanian society but also of the other well known figures and personalities of the Italian politics. The Italian Arberesh used all their possibilities to give an international dimension to the Albanian case as a factor of stability in the Balkan region and beyond. In order to express the obove problematic we have exploited a rich archival literature represented by the dense correspondence of De Rada with other known personalities of that time such as the Romanian princess with Albanian origin Dora D'istria (Elena Gjika), we have used the political Testament of De Rada, by viewing it in a comparative context with the studies of other Albanians and foreign authors.
\end{abstract}

Keywords: "Arber's flag" "The Albanian Nation" administrative autonomy, Jeronin De Rada, Dhimiter Kamarda.

\section{Introduction}

The Arbores community in Italy, refering to the statistics of the time, at the end of the XIX century comprised 200 thousand Arbores, were spread in 80 colonies, with two main units in Napoli and Palermo. ${ }^{1}$

After the ' 50 s of the XIX century, in South Italy it started a convulsive movement of the Arbores community, as a strong support towards the affirmation of the ethno-cultural Albanian identity. The most distinguished representatives of this movement were important personalities of literature among the Italian-Albanian Arbores community, who had managed to preserve the pure mother tongue, the Albanian customs and tradition. A movement likes this, which in the beginning had an individual character, would soon evolve and also be reflected in the periodical Italian-Albanian press entities. Through this, the Arbores' literary and artistic composition would become very famous, and at the same time there were introduced platforms of political ideas, conceptions and judgments regarding the political status of Albanian territories at the end of the XIX-th century.

1Stavro Skëndi, Zgjimi kombëtar shqiptar,(The Albanian national awakening) (1878-1912), translated by Skënder Luarasi and Nestor Pravishta, Phoenix, Tirana: 2000, p. 206. 


\section{In addition of ethno-cultural affirmation}

Albanian Renaissance cannot be understood without the literary composition of the most well-known Arbores'representatives De Rada, Zef Skiroi, Anselmo Lorekio etc.

\section{-The first period of their activism includes the period 1850-1880.}

Nationalism motivated the Arbores Jeronim De Rada from Machia Albanese of Kozenca to write and publish in the Italian press articles about the Albanian National Case. To reach this goal, he would try to make the most of Italian press like "Calabrese" magazine with who collaborated also Vincenzo Dorsa, Giuseppe Krispi and other Arbores writers. He took advantage from this opportunity given to him to publish some important articles regarding the ancient Pelasgian origin of Albanian people and language. Meanwhile he was looking for ways and laying the foundations of Arbores press, which was first documented with the first publishing in Albanian language and Italian of the newspaper "L'Albanese d'Italia" (The Albanian of Italy). ${ }^{1}$

Articles published in the newspaper "L'Albanese d'Italia" had generally the National character, which would be emphasized through publication of parts from poems "Kwngwt e Serafina Topisw"(songs of Serafina Topia) and fragments from "Vallja e haresw sw madhe" (The dance of the great happiness) of Anton Santori. He also published other compositions about traditional Albanian customs. De Rada used his journalism skills to make the Albanian National Case famous worldwide. Thus, Elena Gjika named this newspaper "prognosis of the Albanian National Movement".

Meanwhile, since 1862, in his compositions Vincenzo Dorsa would reflect not only the Pelazgian origin of Albanian language, but at the same time he would try to emphasize the convergence between Albanian language and Latin \& Greek languages, as an essential feature of proximity and collaboration between Albanians, Greeks and Italians. ${ }^{2}$ The Arbores Dhimitwr Kamarda would also support this idea as he was a deep connoisseur of foreign author's works about Albanian language.Through his studies, he would insist merely on the emphasizing of the common origin of Albanian and Greek language stating that: "From the Pelasgian trunk there were created two branches, one was Albanian and the other one Greek'3and consider language as a tool for bridging collaboration and familiarity between Balkan neighbor countries. It's important to mention that during the period of the Congress of Berlin's proceedings, he really hoped in the support of the British diplomats. Since holding correspondence with them, De Rada was very optimistic about their positive attitude toward Albanian National Case, especially the one of Liberal Prime Minister Gladstone with whom he had a lot of correspondence. Stating his ideas, Gladstone, supported Albanian's demand of self-government through local autonomy. ${ }^{4}$

\section{-The period of activism during 1881-1900}

In the second phase of the Arbores activism, after the collision of Prizren's confederate in March 1881, they would strongly intensify their efforts in some specific directions; in reviving their nationalism in supporting the political Renaissance for enriching the cultural movement, for national language and literature, for the conscious awakening of Albanian people regarding politics, and their union in their motherland but also in the diaspora.

In addition, through perseverance of De Rada and other compatriots in the diaspora,on August $20^{\text {th }} 1883$ it was published the second Arbores magazines "La Bandiera Dell'Albania"(Albanian's flag).

The magazine "La Bandiera Dell 'Albania" (1883-1887) represents the first Albanian press institution, in the period of organizing the National Movement towards a new concept. ${ }^{5}$ In the beginning it was published as a social, cultural, folkloric,

\footnotetext{
Ilbid., p. 116.

2 Nathalie Clayer, Në fillimet e nacionalizmit shqiptar (At the beginning of the Albanian nationalism), botimet Përpjekja, Tirana: 2007, p. 183.

3lbid. p. 188.

4Jeronim De Rada, Autobiografia, translated by Jup Kastrati, Onufri, Tirana: 2002, 47. The letter of 26 July 1880.

${ }^{5}$ Stavro Skëndi, Zgjimi kombëtar shqiptar, (The Albanian national awakening) (1878-1912), translated by Skënder Luarasi dhe Nestor Pravishta, Phoenix, Tirana: 2000, p. 115.
} 
artistic and linguistic magazine, but very soon it devolved these bounds. Apart from the coverage of Pelasgian origin of Albanian language, announced by Dhimitwr Kamarda'and De Rada, the magazine covered thoroughly subjects of the national politics, evoking the important developments of Prizren's Confederate and a series of articles like the one entitled "Ç'i duhet Shqipwrisw?" (What does Albania need?). There are announced a couple of political ideas with planning character, like the legitimate right of Albanians on creating a common villayet which would include gegs and tosks and would be governed with democratic principles. De Rada tried to give international dimensions to the Albanian National Case, considering the existence and acknowledgement of the Albanian nation in the international context as crucial. On the other hand, he evaluated the fair solution of the Albanian National Case as a fundamental factor towards peace and security not only in the Balkan but also further. ${ }^{2}$ Guided by such ideas, De Rada choses and publishes poems and verses, historical literacy about Arbores genealogy and their role in the country's future. He kept enhancing the idea that in Italy there was enough infrastructures to organize national activism for Albania and Albanians. The magazine was expanded even outside Italy, not only in countries where there were Albanians like Greece, Romania, Turkey, Bulgaria, Egypt etc. But also in Austria and France.

In the magazine "Fiamuri i Arbwrit" a lot of Arbores writers and publicists published, like Pjetro Kiaraand Gavril Dara Junior, Alfos Kinigoand Zef Skiroi; the distinguished Renaissance activists, Sami Frashwri and Jani Vreto, Filip Shiroka and Gjergji Qiriazi, Visar Dodani, Dora d'Istria and Nikolla Naço; but also a couple of foreign Albanologs and scholars. That's why Professor Zijahudin Kodra, would state: "We can say that "Flamuri i Arbwrit" it's the magazine of the periodic Albanian press that united Albanian intelligence of the time, expanded worldwide". ${ }^{3}$

In this magazine would introduce his literacy compositions, a well-known poet of Arbores Zef Skiroi, whom together with De Rada and Kamarda would vigorously contribute in bridging relations between two sides of Adriatic. ${ }^{4}$ In 1887, he started to publish the magazine with literal character "Arbri i ri"(New Arber), which would replace the magazine "Fiamurin e Arbwrit" of De Rada. Despite its literal character, the articles published in this magazine, would also have national content, evoking the glorious past of Albanians and their rights of self-determination. ${ }^{5}$ n addition, the fulfillment of Arbores main goal for national unification, was reflect in Dora d' Istria's idea: "Without literal Renaissance, the political Renaissance cannot happen at all"... most important efforts are not "patriotic" declarations or manifestation, but the awakening of intellectualism, who's the main source of every social activism and every real development." Meanwhile, Elena Gjika states also the ways that would liberate Albanians from inferiority. According to her, expansion of education and scholarship, the creation of Albanian cultural and educational institutions, the foundation of an Albanian Academy, the composition of an Albanian vocabulary, represented the ways and efforts that would bring the Albanians towards their political unification. ${ }^{6}$

\section{Activism of Italian-Albanian associations and committees}

In the end of the XIX century, in diaspora there were created a couple of Albanian associations and committees. Among them, the most active ones would result the Albanian colonies in Bucharest, Bulgaria, USA, Egypt etc. On the other hand, even Italian-Albanian associations and committees would play a key role, as they were established by the most distinguished representatives of Arbores community in South Italy. Their intensive activism was because the Arbores of Italy were entitled with more freedom than Albanians in the other colonies. In the last years of XIX century, the activism of the Italy's Arbores would reach a higher organizing phase, manifested with the foundation of the association "Societa Nazionale Albanese" in 1895. ${ }^{7}$ Its main activities would result in accomplishing of certain objectives, among which the most important include:

\footnotetext{
${ }^{1}$ Dhimitër Kamarda was an Arbores priest of liberal tendency.

2 "Fiamuri i Arbërit" (The Albanian flag), september 1883, the article is entitled: "Austria dhe Shqipëria" (Austria and Albania). Mendimi politik e shoqëror i Rilindjes Kombëtare Shqiptare (The political and social thinking of the Albanian national Renaissance), vol. I, Triana : 1971, p. 336

3Ylli (The Star) Scientific magazine, nr. 7, Tirana: 1952.

4Stavro Skëndi, Zgjimi kombëtar shqiptar, (The Albanian national awakening) (1878-1912), translated by Skënder Luarasi and Nestor Pravishta, Phoenix, Tirana: 2000, p. 115.

5lbid.

${ }^{6}$ A letter sent to Dora d'Istria in 1866. Dhimitër S. Shuteriqi, Through the literary century, Studies, Tirana: 1973, p. 150.

${ }^{7}$ Stavro Skëndi, Zgjimi kombëtar shqiptar, (The Albanian national awakening) (1878-1912), translated by Skënder Luarasi and Nestor Pravishta, Phoenix, Tirana: 2000, p. 202.
} 
- The organization of some linguistic Congresses, the first one held in Corigliamo Calabroin 1895, where Francesko Krispi was elected President of Honor and the second one held in Lungro of Calabrian 1897.

- $\quad$ The efforts of unifying a common alphabet in addition of proper writing and learning of the Albanian language.

- The compilation of an Albanian dictionary.

- $\quad$ The wide collaboration with Albanians living in the Albanian territories.

Moreover, in 1898, "Societa Nazionale Albanese" association would submit a memorandum to the High Court, demanding the acknowledgment of Albanian language as national language and the opening of schools in Albanian language in Albanian villayets. Therefore we can state that the activism of this association had pronouncedly political character, reflected on its demand on the creation of a United Albanian Villayet ${ }^{1}$. Such demand was in complete coherence with the political platform of the Albanian Renaissance Movement.

In addition to this activism, in April 1897 in Napoli there was created a Political Albanian Committee, headed by Markezi d' Auletta, who asked to the Italian government to support the Albanian National Movement. ${ }^{2}$ By the end of the XIX century, the activism of the Italian-Albanian associations, whose representatives would not all share the same political attitude as De Rada, would regardless intensify and continue with demands to the High Court. What's interesting about this period, is a project introduced in one of the petitions addressed to the High Court in June 1899 from the Italian-Albanian community in Italy, through which was proposed that the villayets of Shkodra, Kosovo, Manastir, Selanik and Janina should create a common villayet with an autonomous status denominated "Regional Commissariat for Imperial properties in Balkan Peninsula" dependent on Istanbul ${ }^{3}$. As main institution of this villayet would be the General Committee residing in Manastir, on who would depend on the Special Commissioners in the capitals of other villayets. As official language in the vilayets would be Albanian, and official language between Regional Committee and Central Government in Istanbul would be Turkish. ${ }^{4}$ We think that such project would not adapt with the ethnic-linguistic circumstances in the Albanian villayets.

Also, in 1900 it was created an Albanian Committee in Rome, Italy. In the same year it was founded also the National Albanian League with branches in all Italian-Albanian territories. ${ }^{5}$

In the early XX th century, the Arbores movement would consolidate and fortify and concentrate mostly in the organization of Congresses with educational-cultural character but at the same time with authentic political aims. The Congress held in Napoli in 1903, would demand from the Italian government to provide more scholarships for Albanians, teaching Albanian language in public school of Arbores community in Italy, the foundation of a central magazine in Rome in a couple of languages including the Albanian language also. ${ }^{6}$

The biggest accomplishment of the Congress of Napoli, would be the establishment of a Cathedra in the Oriental Institute of Napoli in Albanian, in which would practice and profess his activity the Arbores poet Zef Skiroi. ${ }^{7}$

But we can state that, regardless the cultural and educational activism with authentic political goals, the most distinguished representatives of the Arbores elite in Italy would not share the same points of view regarding the form, methods and approaches that should be implemented to reach the political unification of Albanian territories. Divergences between them would be easily detected by the creation of two main streams; the revolutionary and the moderate one, who would reflect different outlooks in the political future of Albanian territories. Main representative of revolutionary stream Zef Skiroi would see the process of gaining the Albania's independencethrough a thorough revolution and insurgence to liberate from the Otoman Empire. While, the liberal side represented by De Rada and Anselmo Lorecchio not only were categorically against such statement, but also considered the existence of the Otoman Empire as a necessary affliction who would protect Albanians from the risk of Balkan nationalism. According to them the emancipation and the cultural awakening of Albanians was the right way toward the foundation of an independent Albanian country, emphasizing also the fact that Albanians lacked the support of the International factor which was crucial in the process of creating a country among Balkan people.

\footnotetext{
${ }^{1} \mathrm{An}$ administrative unit in the frame of the Ottoman Empire in which the Albanian territories were included in the $20^{\text {th }}$ century 2Markezi d' Aulettaclaimed to be a descendent of Skanderbeg's kinship

${ }^{3}$ Stavro Skëndi, Zgjimi kombëtar shqiptar, (The Albanian national awakening) (1878-1912), translated by Skënder Luarasi and Nestor Pravishta, Phoenix, Tirana: 2000, p. 203.

4lbid. p, 204.

${ }^{5}$ Stavro Skëndi, Zgjimi kombëtar shqiptar, (The Albanian national awakening) (1878-1912), translated by Skënder Luarasi and Nestor Pravishta, Phoenix, Tirana: 2000, p. 204-205

6lbid, p.205.

7 bid.
} 
Regarding the issue, we think that the Liberal's point of view stood closer to the political-historical reality of Albanian territories and Balkan region by the end of the XIX century until the first decade of the XX century. In this period the Albanian National Movement had to face not only the opposition of the Ottoman Empire for not giving autonomy to the Albanian territory but at the same time it had to face the imminence coming from its Balkan neighbors and nationalists (Serbia and Greece).

Furthermore we have to state that until1912 the Albanians still didn't have the International support, highly essential in the process of creating a state, standing alone against all. 